\title{
The Role of Hospital Public Relations in 4.0 Era
}

\author{
$1^{\mathrm{st} *}$ Nadia Wasta Utami \\ Communication Department \\ Universitas Islam Indonesia \\ Yogyakarta, Indonesia \\ nadia.wasta@uii.ac.id
}

\author{
$2^{\text {nd }}$ Rifka Alifiana \\ Communication Department \\ Universitas Islam Indonesia \\ Yogyakarta, Indonesia \\ rifka.alifiana97@gmail.com
}

\begin{abstract}
This article discusses mainly about how the role of hospital public relations, especially in the 4.0 era. The study focused on public relations from several hospitals in Yogyakarta namely PKU Yogyakarta Hospital, PKU Gamping Hospital and Wates Regional Hospital. From this research it is known that public relations in the 4.0 era played a different role between one hospital and another. The role of hospital public relations in general is still dominated by work as a communication technician. Technical activities as public relations include making and sending various press releases to the media, attending and documenting various events, managing websites, and creating graphic designs for social media as well as hospital publications. The role of hospital public relations in managerial aspects of communication in the form of roles as expert prescriber, problem solver as well as communication facilitator appears to be very limited.
\end{abstract}

\section{Keywords-Role, Public Relations, Hospital}

\section{INTRODUCTION}

PR has the duty to form a good relationship between internal and external public. In relation to hospital public relations, public relations becomes one of the parts that largely determines how good communication is created between the hospital and patients and vice versa. The existence and role of public relations in a hospital becomes a necessity, especially in the middle of the industrial era 4.0 which makes it easy for humans to share news through various media.

The urgency of the hospital's public relations role has been tested several times with the number of cases sticking out in the media. Call it the Prita Mulyasari case with Omni International Hospital. The defamation alleged by Omni International Hospital due to Prita's personal e-mail spread on the internet triggered the hospital to claim hundreds of millions of rupiah in damages. This makes many parties become unsympathetic to the Omni hospital and they gain support for Prita by forming cyber community among bloggers and facebookers [5]. This movement then succeeded in leading the opinion of the media as well as the public to fight the criminalization of the Omni Hospital against Prita. The case that injured the image of the Omni International Hospital illustrates the importance of public relations, especially in hospital crisis management.

From the explanation above can be seen the large role of hospital public relations in various situations that exist. Reference [10] shows clearly that the role of public relations has an effect of $74 \%$ on the quality of health services, especially at Tampan Hospital in Riau. In addition there are several other studies that show the role of hospital public relations is very broad and includes four concepts of [4], namely as an expert prescriber, communication facilitator, problem solving facilitator, and communication technician [1][6]. Based on these studies, the role of hospital public relations can be said to be very important for the hospital's activities and policies.

This research uses descriptive qualitative method. This is because this study aims to explain how the role of public relations in hospitals in the 4.0 era, is not intended to seek or explain relationships and not test hypotheses or make predictions [9]. The object of this research is public relations from several hospitals in Yogyakarta, namely PKU Yogyakarta Hospital, PKU Gamping Hospital and Wates Regional Hospital. Data collection used was the interview and observation methods. This study aims to determine how the role of hospital public relations in the 4.0 era.

\section{RESULT AND DISCUSSION}

There are so many research explain about the urgency of public relations in hospital. In [11] research it is seen how the role of public relations in maintaining reputation in Dr. Moewardi Hospital Surakarta. Another interesting research explain that the corporate PR practitioner's ability to manage internal stakeholder relationships is a prerequisite to successful external relations. PR practitioner as a technician versus a strategic manager can be a barrier to build a good relations with internal and external public. So these two role of PR, both as technician or strategic manager have to be balance to expand the PR role to the whole of organization [2].

So many experts conceptualized various organizational roles for public relations practitioners, which later were consolidated into the manager and technician roles. Technicians tend to produce and disseminate materials based on what the client or manager deems important; managers participate in decision-making, conduct research and evaluate their success [4]. Based on the findings obtained discussion can be drawn that the role of Yogyakarta hospital public relations in the era of 4.0 are as follows:

\section{A. Expert Prescriber}

Public Relations acts as an expert and defines the problem, makes the program and is responsible for the implementation of the public relations program. Helping management with experience and skills to find solutions to the solutions faced by the company [3]. In carrying out their duties, hospital public relations performs different roles as expert advisors. Of the three hospitals studied, only PKU Muhammadiyah Yogyakarta Hospital public relations who played a role in 
providing input to top management regarding some issues that are considered controlled by the public relations field itself. $\mathrm{PR}$ is considered an expert to deal with these problems so it will be very reliable. Whereas public relations from the other two hospitals does not yet have the role of expert prescriber due to various reasons such as lack of public relations human resources, limited knowledge as well as experience as a publicist.

\section{B. Communication Facilitator}

Public relations practitioners act as intermediaries who maintain the quality and quantity of two-way communication between the organization and its public. Public relations officer functions as a liaison, interpreter, and mediator who seeks to remove communication barriers. The aim is to provide the information needed by management and the public to make mutually beneficial decisions [3]. In this role, hospital public relations has the task of being a communication facilitator with a variety of diverse activities in each hospital. Public Relations can play a role in organizing internal communication between employees in the hospital environment, between employees and management. In addition to internal communication, public relations also plays a role in the hospital's external communication with the public. This can be seen from the public relations duties in information provider as well as a spokesperson in a variety of external hospital events.

\section{Problem Solver Facilitator}

Public relations practitioners help the organization's management to find solutions to organizational communication and relations problems. This role involves members from other fields in the company. The role of hospital public relations as a problem solver in practice experiences differences in the intensity of public relations involvement in the process. Public Relations can play a role as a mediator and even a central figure, especially in solving problems in the form of complaints. Starting from serving when the complaint comes in, overseeing the process until the completion of the complaint by giving compensation or gifts. Different intensities are shown when in the role of public relations solver is in a position of liaison between external parties and top management. PR is present but does not significantly play a role in providing solutions to existing problems.

\section{Communication Technician}

In this role public relations is expected to have expertise in the fields of journalistic-writing communication, editing, audio, visual, graphic and message production needed to carry out public relations programs. In the role of public relations communication technicians not involved in organizational decision making. Of the overall roles that exist in hospital public relations, the role as a communication technician is a role that is always exist, sometimes even dominating public relations work in several hospitals. Technical activities as public relations include making and sending various press releases to the media, attending and documenting various events, managing websites, creating graphic designs for social media as well as hospital publications, and taking the role of event organizers in various events created by hospitals. From preparing proposals for events, places, to being reception guests, welcoming a variety of guests who come to the hospital. The role of this communication technician mostly takes up most of the public relations time, by that public relations cannot touch the aspect of the role of the communication manager.

The development of the times requires public relations to have new competencies. PR INDONESIA The teacher who is the founder of EGA briefings, Elizabeth Goenawan Ananto, in PR Indonesia Magazine even divides the new competencies that PR must have into three levels. First level, for novice practitioners. PR at this level must improve IT-based competence and have a high curiosity (intellectual capacity). The second level, managerial PR. At this level, public relations needs to understand the benefits of data obtained from research, analytical and interpretative skills, and coordination with relevant parties. While at the third level, or strategic PR, they must have closeness with the CEO or decision maker, the ability to think as a team leader, not just a practitioner of communication, and provide input [7].

SBM ITB's Director of Communication \& Alumni Relations Nurlaela Arief highlighted the basic fundamentals of PR professionals that must still be had by PR, in addition to four new skills such as data analytics, influencers, social media handling, and content creation. However, among all of them, the most important thing is the ability of data analysis accompanied by effective and clear communication. In line with this, social media task become a common part of public relations role nowadays [8]. Social media task even become a specialist for some public relations officer so public relations will spend a lot of time doing this role.

\section{CONCLUSION}

From this research it is known that public relations in the 4.0 era played a different role between one hospital and another hospital. It is in accordance with the opinion of Elizabeth Goenawan Ananto, assessed that there are five conditions that can influence the trend of public relations (PR) as a management function in 2020. The five intended conditions include the country's political system, socioeconomic conditions and the development of the situation as a result , the maturity of the media system, the presence or absence of pressure from groups (pressures groups), as well as the qualifications of the PR practitioners themselves.

The role of hospital public relations in general is still dominated by technical communication work. The role of hospital public relations in managerial aspects of communication in the form of roles as experts, problem solvers as well as communication facilitators appears to be very limited. This is due to various reasons including the policies of the hospital itself, the organization's awareness of the urgency of public relations and the organizational structure that places public relations in different positions starting from a line management position that is close to the top leadership, or a line management position that is only carry out orders from its leaders.

\section{REFERENCES}

[1] S. Adhiani. "Peran humas rumah sakit Islam Ibnu Sina dalam melaksanakan misi pelayanan kesehatan yang prima dan islami di Pekanbaru" Jurnal JOM FISIP Vol. 4 No. 1 Februari 2017

[2] L.A Cardwell, S. William, A. Pyle, "Corporate public relations dynamics: internal vs. external stakeholders and the role of the practitioner." Public Relations Review 43 (2017) 152-162

[3] Cutlip, Scott M.; Center, Allen H.; Broom, Glen M, Effective public relations. Pearson Prantice Hall. 2006 
[4] Dozier, David. M; Broom, Glenn, "Evolution of the manager role in public relations practice." Journal of Public Relations Research Vol 7 1995

[5] Hadi, M. Aliyulloh. "Gerakan sosial cyber community: study ada gerakan komunitas blogger dan facebooker mendukung Prita Mulyasari http://eprints.umm.ac.id/32233/

[6] Handayani, Fikhi. Peranan humas dalam meningkatkan citra rumah sakit kusta Dr Tadjuddin Chalid Makassar. Repository.unhas.ac.id

[7] Kartika, Ratna. Tantangan PR 2020 semakin beragam. PR Indonesia Magazine. Edisi 58 | Th V | Jan 2020

[8] Lee, Nicole M; Sha, Bey-Ling ; Dozier, David M; Sargent, Paul. The role of new public relations practitioners as social media experts. Public Relations Review 41 (2015) 411-413
[9] Rakhmat, Jalaluddin. Metode penelitian komunikasi. Bandung : Remaja Rosda Karya. 2001

[10] Sikumbang, Yuni Asnidar. Peranan humas terhadap mutu pelayanan kesehatan Rumah Sakit Jiwa Tampan Provinsi Riau. Repository.uinsuska.ac.id

[11] Wahyono, Budi. Peran public relations dalam mempertahankan reputasi organisasi (studi kasus terhadap pelayanan pasien rawat inap Rumah Sakit dr. Moewardi Surakarta)http://v2.eprints.ums.ac.id/archive/etd/18680/6/5 